\title{
В.В. Филичева
}

\section{Ф. СОЛОГУБ - РЕДАКТОР В ИЗДАТЕЛЬСТВЕ «ВСЕМИРНАЯ ЛИТЕРАТУРА»}

\author{
Работа выполнена при финансовой поддержке РГНФ (проект № 16-04-50145).
}

\begin{abstract}
Рассматривается вопрос о редакторской деятельности Ф. Сологуба в издательстве «Всемирная литература» (1918-1924). Подробно освещена работа над «Избранными сочинениями Ги де Мопассана», для которых Сологуб выступил не только как переводчик, но и как редактор, автор примечаний и вступительных статей. Проанализированы принципы, по которым работало издательство, пытаясь изменить саму форму работы переводчиков и редакторов по подготовке книг. Ключевые слова: перевод; редактирование; «Всемирная литература»; Ф. Сологуб; Ги де Мопассан.
\end{abstract}

В период сотрудничества со «Всемирной литературой» Ф. Сологуб выступал и как переводчик, и как редактор чужих переводов. Это двойственное положение дает материал для наблюдений, невозможных на других этапах его переводческой деятельности, которые уже неоднократно становились предметом исследования [1-4].

Один из периодов активной деятельности Сологуба в области переводов в рамках работы издательства приходится на время после 1910 г., когда он совместно с сестрами Анастасией Николаевной и Александрой Николаевной Чеботаревскими участвует в деятельности издательства 3.И. Гржебина «Пантеон» [5]. В 1920-е гг. отношение Сологуба к переводам несколько изменилось и выразилось в достаточно резком высказывании: «Последние семь лет я занимаюсь переводами. Обидно, что не имеешь возможности заняться литературой» [6. С. 406]. Однако эта фраза может быть воспринята и как кокетство со стороны писателя. Подчеркивая «практическую» направленность работы над переводами (из заработка), сам он отрицательно относился к возможности правки его поэтических переводов редакторами: «Считая себя первоклассным русским поэтом, $<\ldots>$, я не могу согласиться на редактирование моих стихотворных переводов какою бы то ни было поэтическою коллегиею», - так писал Сологуб заведующему издательством А.Н. Тихонову о своем плане перевода поэмы Ф. Мистраля «Мирейо» в июне 1919 г. [7. С. 133]

К прозаическому тексту писатель не высказывал столь трепетного отношения. Переизданные в народной и в основной сериях «Всемирной литературы» книги зачастую подвергались однотипной правке: все иностранные слова были даны сразу в переводе, убраны обращения типа «m-lle» и т.п. В издании романа Г. Банга «Четыре беса» во всем тексте наименование «бесы» было заменено на «дьяволы». Перевод «Кандида» был сильно отредактирован стилистически (либо Ф.Д. Батюшковым, который являлся и автором предисловия и примечаний, либо самим Сологубом по указанию Батюшкова) [8-12].

Во «Всемирной литературе» Сологуб все чаще сам выступал как редактор. В разное время он заключил договоры на редактирование или получил гонорар за редактирование следующих изданий: «Антология французских поэтов» (совместно с Вс. Рождественским и Б. Лившицем) - апрель 1923 г.; «Финк и Флидербуш» А. Шницлер (пер. Бернштейн); «Избранные сочинения» М. Метерлинка ${ }^{1}$; «Стихи» П. Верлена (пер. В. Брюсова; стих. «Epiloque. III» Н. Гумилёва), а также на «Избранные сочинения Г. де Мопассана» [13]. Работу над двумя последними охарактеризуем подробнее.

Редактор во «Всемирной литературе» отвечал, в том числе, за состав сборника и снабжение тома примечаниями. В библиотеке Пушкинского Дома, куда были перевезены архив и собрание книг Ф. Сологуба после его смерти, сохранились книги с редакторскими маргиналиями, что позволяет нам проследить работу писателя. При составлении и редактировании сборника стихов П. Верлена в переводах В. Брюсова был использован имевшийся у Сологуба экземпляр книги брюсовских переводов [14]. По каким-то причинам сборник с переводами из П. Верлена не вышел, хотя Сологуб пытался договориться об этом с А.Н. Тихоновым. По первоначальному плану сборник должен был включать 105 стихотворений, и не только в переводах Брюсова, но и в его собственных. У Брюсова переводов было больше, и при наличии двух вариантов Сологуб выбирал свой (37). В сравнении с изданием 1908 г. [15] для своих переводов Сологуб изменил некоторые названия и исключил варианты, помещенные в основном тексте и вызвавшие в свое время недоумение критики. Гонорар за редактирование Верлена (1 430 строк) был выдан 7 февраля. По замыслу Сологуба, в сборник следовало включить «еще переводы нескольких стихотворений», которых не было ни у Брюсова, ни у самого писателя, в связи с чем, видимо, предпринималась попытка собрать недостающие тексты. Видимо, поэтому Сологубом был отредактирован текст еще одного стихотворения - в переводе Н. Гумилёва («Эпилог. ІІІ») [16. С. 240-241]. Сборник стихов Верлена во «Всемирной литературе» так и не вышел.

Сологуб также выступил как редактор, составитель, автор примечаний и вступительных статей в издании «Избранные сочинения Ги де Мопассана». Для «Всемирной литературы» Сологубом были составлены несколько томов, включавших произведения Мопассана в переводе Ан.Н. и Ал.Н. Чеботаревских. Большая часть этих текстов ранее была опубликована в издательствах «Шиповник» и «Пантеон»: «Наш милый друг» ${ }^{2}$ «Пышка», «Пьер и Жан», «Сказки Бекаса», «Иветта и другие рассказы», «М-1le Фифи и другие рассказы», «Сестры Рондолли и другие рассказы», «Монт-Ориоль», «Жизнь», «Напрасная красота и дру- 
гие рассказы». Напечатаны были два из них [17, 18]. О работе над подготовкой остальных произведений остались только архивные свидетельства.

В личной библиотеке Сологуба сохранился экземпляр тома рассказов Мопассана в издании «Шиповника» «Лунный свет и другие рассказы» с его карандашной правкой [19]. Титульный лист после правки получил такое же оформление, как и у других томов Мопассана во «Всемирной литературе». В самом тексте переведены иностранные названия (Rue de Martyres - улица Мучеников, и т.п.). Исправлены стилистические ошибки перевода:

«Главная масса детишек наконец рассеялась»«Толпа детишек наконец рассеялась» [19. С. 17].

«Родные долго колебались» - «Родители долго колебались» [Там же. С. 32].

«Наконец, сняв верхние вещи, женщины уселись» - «Наконец, сняв дорожные одежды, женщины уселись» [17. С. 50].

«Пока я стоял в экстазе» - «Пока я стоял в восторге» [19. С. 63].

«Франсуа между тем обожал “Кокотку”. Он дал ей это имя без умысла, несмотря на то, что вполне она его заслужила» - «Франсуа, однако, обожал "Кокотку”. Он дал ей это имя без умысла, хотя она его вполне заслужила» [Там же. С. 77].

Судя по сохранившимся в архиве Сологуба документам, этот сборник рассказов должен был входить вместе со сборником «Сказки Бекаса» (шестой том в издании «Пантеона») в восьмой том «Избранных сочинений Ги де Мопассана» издания «Всемирной литературы». В седьмой том должны были входить сборник «Барышня Фифи» и пять рассказов: «Пышка», «Дом Телье», «На воде», «История девушки с фермы», «В семье». Там же находится предисловие «Рассказы Мопассана» [20], которое вместе с примечаниями к седьмому тому было сдано в издательство 28 мая 1919 г. (примечания к восьмому тому - 31 мая).

В восьмом томе вслед за основным корпусом текстов были помещены: «Рассказы, вошедшие в сборник “Сказки Бекаса”, вышедший в 1883 г., издание Виктора Гавара; Два рассказа, не включенные Мопассаном в сборники и вошедшие в “Сказки Бекаса" в издании Л. Конара $<\ldots$. >; Рассказы, вошедшие в сборник Лунный свет, изданный В. Гаваром в 1884 г. $<$..>; Рассказы, включенные в этот сборник в издании 1888 г. <.. >» [Там же. Л. 23-25]. В издании «Пантеона» некоторые рассказы (например, «Могила» и «Заметки путешественника») уже были включены в том и помечены в оглавлении как неизданные.

Составленные Сологубом примечания в основном сводятся к библиографическим ссылкам, почерпнутым писателям из издания в «Пантеоне»: название оригинала, место и год издания. И только у некоторых текстов примечания были расширенными ${ }^{3}$.

Работа Сологуба в качестве редактора во «Всемирной литературе» строилась по плану, регулировавшемуся многочисленными циркулярами-инструкциями корректорам, редакторам, авторам вступительных статей и примечаний. Издательство пыталось изменить саму форму работы над книгами, стремясь к повышению качества переводных изданий. В самих переводах в издательстве не было недостатка, так как в Петрограде было достаточно литераторов, много и успешно переводивших. Скупив большую часть уже готовых, зачастую ранее опубликованных переводов в момент организации дела в конце 1918 и начале 1919 г., издательство столкнулось с необходимостью обработки текстов. Сначала проводилась проверка / оценка перевода, затем шли редактирование с последующей проверкой работы редактора, а далее формирование томов и снабжение их вступительными статьями и примечаниями.

Написание вступительных статей и снабжение примечаниями тома для многих литераторов были новшеством и вызывали трудности. О том, что эта тема была одной из основополагающих для издательства, свидетельствует тот факт, что в литературной студии «Всемирной литературы» 16 февраля 1919 г. в числе первых был прочитан доклад заведующего редакцией А.Н. Тихонова «Вступительные статьи к произведениям иностранных писателей» [21. С. 16].

Начинаясь с характеристики адресата книг («вступительные статьи основного издания имеют в виду среднего интеллигентного читателя с гимназическим образованием»), инструкция, основанная, видимо, на реферате Тихонова, подробно описывает, что должно включать предисловие: источники (основы или темы); творческая история текста (изменения в первоначальном замысле и причины); критический разбор содержания и техники; положение данной книги в ряду других произведений автора; отзывы современников и последующей критики; связь с русской литературой [22. С. 7].

Во вступительных статьях к собраниям сочинений при подаче биографии предлагалось придерживаться следующего плана: по возможности дать «живой облик»; общественная и литературная среда; литературно-критический очерк деятельности писателя (этапы мировоззрения и творчества); анализ приемов писателя, сопоставление с предшественниками и новое - в языке, образах, строении и т.п.; о судьбе его произведений - критика, последующее восприятие, влияние на культуру и литературу своей страны «и в особенности (подробно) связь писателя с русской литературой» [Там же. Л. 6] $]^{4}$.

Объем определялся для общих статей в собрании сочинений в основной серии - 2-3 печатных листа, к отдельным произведениям - 1/2 печатных листа; в народной серии - не должен был превышать $1 / 2$ печатного листа.

Однако провести абсолютную унификацию было невозможно, и в издательстве это понимали: «Указанные размеры отнюдь не обязательны и не должны стеснять авторов»; «вышеизложенные тезисы являются лишь пожеланием Коллегии - не больше - и отнюдь не должны стеснять и ограничивать индивидуальный подход сотрудника к его теме. Цель тезисов внести некоторую планомерность и единообразие в коллективную работу издательства, а отнюдь не в том, чтобы создать мертвый шаблон для “изготовления" вступительных статей, по заданному образцу» [Там же. Л. 11].

При этом все издания должны были складываться в единую картину, чему должна была служить общая 
информационная база: «Каждая вступительная статья должна, помимо прочего материала, заключать в себе сведения относительно влияния данного автора на иностранную литературу и обратно». Предполагая труднодоступность некоторых сведений, которые «часто носят очень специальный характер и отнимают у редактора слишком много времени, отвлекая его от текущей работы», издательство предлагало получать необходимый материал от членов редакционной коллегии издательства [22. Л. 16]. Позднее для облегчения работы редакторов в декабре 1919 г. в издательстве было организовано «Бюро справок», которое возглавил сначала В.А. Чудовский, а затем Н.О. Лернер.

К тому времени Ф. Сологуб написал три предисловия к книгам переводов: к своим переводам из П. Верлена (1908), к изданию романа Ж. Лоррена «Астарта» (1911), а также заметку для Полного собрания сочинений Мопассана в издательстве «Пантеон» «Смертный лик Мопассана» (1912) [15. С. 5-6; 23. С. 5-8; 24].

Однако эти краткие заметки были скорее развитием идей самого Сологуба, выражением отношения к автору произведения, его личного «видения», выявления родственной темы в творчестве того или иного автора. Сологуб таким образом пытался через свою поэтику объяснить чужую, а через собственное понимание творчества переведенного автора рассказать о себе.

В рассуждениях о Мопассане появляются образы Дульцинеи и Альдонсы, близкие творчеству самого Сологуба: «Альдонса, которая Дон Кихоту была только основою для создания сладкой мечты о Дульцинее, для Мопассана была только Альдонсою, единственною подлинною реальностью мира». Те же герои появляются и в Предисловии к Верлену в 1908 г. (повторенном в издании 1923 г.).

«Я переводил Верлена потому, что люблю его. А люблю я в нем то, что представляется мне в нем наиболее чистым проявлением мистической иронии. $<\ldots>$ Для лирического поэта, как для Дон Кихота, нет Альдонсы, есть Дульцинея. Для иронического поэта, как для Санчо-Панса, нет Дульцинеи, есть Альдонса» [25. С. 5].

Еще один пассаж, говорящий больше о Сологубе, чем о Мопассане: «Так влиянием и близостью смерти чаруют блистательные страницы мопассановской прозы. Смеемся, забавляемся, - но “кто жил и чувствовал", не может не почувствовать тайного яда, разлитого в этих страницах».

В предисловии к «Астарте» Сологуб, отметив главную тему романа как «изображение души слишком современной, слишком отравленной ядами сладостными и чересчур пряными ядами нашей городской цивилизации», высказался о современной действительности - оторванности человека от природы и потери им «жажды к жизни» - а из этой неясной жажды, «томящей < ..> душу < ..> горожанина», развивается стремление попасть в «золотой град».

Во «Всемирной литературе» для собрания сочинений Мопассана Сологубом было написано как минимум пять статей к отдельным томам в качестве «Послесловий», опубликовано из них только два и одно хранится в архиве [17. С. 311-315; 18. С. 227-232; 20. Л. 1-14]. Из протоколов заседаний редакционной коллегии издательства известно, что был готов к печати том Мопассана «Жизнь» со статьей Сологуба [26]. А позже - «Наше сердце» со статьей Сологуба, которые были переданы на просмотр Н.О. Лернеру [27]. В послесловиях к изданным книгам Сологуб подробно разбирает произведения.

Анализируя роман «Милый друг», говоря о теме, Сологуб подчеркивает его автобиографичность («газетную среду Мопассан знал хорошо» [17. С. 311]; «Жорж Дюруа сделался чиновником на маленьком жалованьи, как и сам Мопассан» [Там же. С. 313]). А рассуждая о месте этого романа в ряду других произведений Мопассана, сопоставляет его с романом «Жизнь» и рассказами 1885 г., мимоходом говорит о технике и стиле («мрачная картина всеобей порочности и продажности гармонирует в этом романе с теми меланхолическими настроениями, которые с 1885 года все сильнее и явственнее отражаются в произведениях Мопассана» [Там же. С. 314]; «Превосходно изображена в этом романе ежедневная жизнь великого мирового города» [Там же. С. 312]; «Самый стиль Мопассана <..> приобретает в этом романе особенно углубленную ясность. И построение рассказа здесь совсем иное, чем в романе “Жизнь”” [Там же. С. 314]). Не забывает при этом упомянуть и отзывы критики: «роман имел большой успех и встречен был многими хвалебными отзывами» [Там же. С. 315].

Таким же образом строит писатель и статью к тому рассказов. Охарактеризовав творчество Мопассана в первом абзаце, Сологуб приводит множество критических высказываний о писателе и автохарактеристики: «Сам Мопассан говорит о себе: <..>; Поль Нэве говорит о Мопассане: <...; Сам Мопассан в письме в редакцию газеты "Галл" пишет о себе и о своих литературных друзьях: <..>» и т.П. [20. Л. 1-5].

По приведенным фрагментам видно, что подход Сологуба к пояснительным статьям изменился - в соответствии с планом, принятым в издательстве. Чтобы охарактеризовать связи иностранной и русской литературы, Сологуб действовал двумя путями. Первый - это отсылки к Тургеневу или Пушкину. В послесловии к роману «Милый друг»: «Для русского читателя интересно упомянуть, что Мопассан два раза писал о Тургеневе, с которым был очень хорошо знаком <..> [17. С. 311]» (см. также ранее - комментарий к рассказу «Дом Телье»).

Приводя цитату Мопассана из письма, Сологуб комментирует, отражая более свое воззрение: «"Только сам писатель может и должен быть единственным и независимым судьею того, на что он себя чувствует способным...” (Вспомним Пушкина: “ты сам - свой высший суд”)» [20. Л. 8]. В другом послесловии им также использована конструкция со скобками: «(Вспомним, кстати, что и наш Пушкин иногда брал библейский текст в неожиданном применении, напр., “Что в имени тебе моем”)» [18. С. 227].

В послесловии же к «Милому другу» Сологуб будто отвечает на пункт плана, завершая его словами: «В России Мопассан ценился всегда больше, как автор 
рассказов. Романы его у нас меньше обращали на себя внимание. Соответственно этому малому влиянию Мопассановых романов трудно было бы указать в нашей литературе что-нибудь значительное в области романа, что стояло бы в непосредственной связи с “Милым другом". Хотя и можно сказать, что кларизм таких наших современников, как, напр., Кузмин и Алексей Н. Толстой, носит на себе отпечаток влияния Мопассана, но для обоих этих писателей значительнее иные литературные влияния» [17. С. 315].

Однако устраивала ли эволюция редакторских принципов Сологуба само издательство? В отзыве Лернера о томе «Наше сердце» под редакцией и со вступительной статьей Ф. Сологуба говорится: «Статья в большей своей части скомбинирована из отдельных примечаний к Конаровскому изданию романа, однако, без всяких ссылок на источник. В переводе встречается довольно много неточностей, мелких пропусков. Местами редактор, исправляя переводчика, ухудшает самый перевод» [28]. Эта экспертная оценка привела к тому, что было постановлено - статью к печати не принимать.

Издание, о котором говорит Лернер, - наиболее полное собрание сочинений Мопассана [29], по которому осуществлялся и перевод в издании «Шиповника». В «Шиповнике» были также воспроизведены примечания, помещенные в конце каждого текста (первая публикация), и включены рассказы, помеченные как неизданные («inédit»).

Сологуб скомпоновал сведения из французского издания и обобщил их своим текстом-отношением. Наиболее показательна в этом плане статья к роману «Сильна как смерть», собственному переводу Сологуба. В ней приведены не только отзывы критики, но и история работы над текстом и даже варианты перевода пяти заключительных фраз. Сама информативная часть была помещена в издании Конара в приложениях: «Note», где кратко охарактеризована рукопись романа и приведены те четыре варианта заключительной фразы, «Variantes» и «Opinion de la press», в которых помещены отрывки из статей, процитированые и Сологубом.

Однако, как ни странно, именно в тексте этой вступительной статьи более всего проявилось аналитическое и субъективное начало Сологуба-редактора: «...самое название романа указывает, что для автора представление смерти стало близким, как представление любви. Название взято из Библии. (Вспомним, кстати, что и наш Пушкин иногда брал библейский текст в неожиданном применении, напр., “Что в имени тебе моем”)» [18. С 227]. Эта трактовка романа указывает на близость темы самому писателю и объясняет выбор текста для перевода (вспомним хотя бы финал пьесы «Победа смерти» (1907): «И верьте Смертию побеждает Любовь, Любовь и Смерть - одно» [24. С. 155]).

В той же статье встречаются и другие сологубовские интерпретации: «Тягостное состояние автора сказалось явственно и во внешнем виде его труда. Рукопись романа <..> испещрена поправками и вставками» [18. С. 228]. Говоря о трагедии творца, он выстраивает образ писателя, создавая таким образом из жизни сюжет, творимую легенду: «От него все еще ждали интересного повествования о внешних событиях жизни, о нелепых поступках безумного человеческого стада. Но Мопассан уже не мог быть прежним беззаботным рассказчиком» [Там же. С. 232].

И если в самом издательстве вступительные статьи Лернером были забракованы, то в немногочисленной критике выход нового издания перевода Сологуба «Сильна как смерть» был воспринят как хорошо подготовленное издание: «О достоинствах перевода говорит имя переводчика. Остановимся только на статье Ф.К. Сологуба, который выясняет значение этого романа в истории творчества Мопассана и характеризует значение самого произведения. Для этого автор статьи пользуется письмами самого Мопассана, относящимися к периоду создания романа» [30. С. 2].

Признание близости произведения и его темы самому переводчику, по сути, оказывается если не такой же, то очень похожей на более раннюю формулировку: «Я переводил Верлена, потому что люблю его». Эти работы стали этапом в творческой биографии Сологуба, когда писателю пришлось перестраивать свою деятельность под новые требования и правила. И как мы видели, ему удалось это сделать, не потеряв собственного слова. Часть отредактированных Ф. Сологубом произведений постигла участь большинства переводов во «Всемирной литературе», другие были напечатаны в издательстве «Книжные новинки»: «Пьер и Жан» (1926, 2-е изд.: 1927), «Монт-Ориоль» (1927), а в издательстве «Сеятель» переизданы романы «Сильна как смерть (1925) и «Милый друг» (1926). В дальнейшем же перевод Ан. Чеботаревской «Милый друг» выходил под редакцией А.А. Смирнова (Л., 1936; М., 1944), а перевод Сологуба, так же как и его послесловия, не переиздавались.

\section{ПРИМЕЧАНИЯ}

\footnotetext{
${ }^{1}$ Книга переводов из Шиллера не была опубликована. Возможно, имеются в виду Полина Самойловна Бернштейн, переводчица с немецкого, или один из ее сыновей Сергей или Игнатий Игнатьевич (псевд. Александр Ивич). Для собрания сочинений М. Метерлинка Сологубом в разное время были отредактированы: «Там, внутри», «Амадина Палам», «Принцесса Мален», «Пелеас и Мелизанда», «Непрошенная гостья», «Слепая», «Семь принцесс», «Смерть Шентуа», «Аглавена и Селизенда», «Ариадна и синяя борода», «Сестра Беатриса», т.е. в основном то, что было в переводах Анастасии и Александры Чеботаревских. А также вступительная статья Н. Минского, ранее включенная в издание журнала «Нива».

${ }^{2}$ Название романа Мопассана «Bel Ami» было более точно передано в издании «Всемирной литературы»: «Милый друг».

${ }^{3}$ См., например: «Пышка» (Bouie de Suif). Напечатано в сборнике «Вечера в Медане» 1880 г. Подлинное имя Пышки - Адриенна Легэ. Во время войны жила в Руане. Остальные действующие лица также списаны с натуры. Событие, рассказанное здесь, произошло в действительности, хотя сама Адриенна Легэ до конца своей жизни (умерла вскоре после смерти Мопассана) настойчиво утверждала, что немецкий офицер не добился от нее того, чего хотел. <..> Дом Телье (La Maison Tellier). < ..> О плане этого рассказа Мопассан часто говорил своим друзьям, между прочим и Тургеневу. <..> Сборник имел очень большой успех; в первые два года разошлось 12 изданий. Книга посвящена
} 
Тургеневу. Он способствовал переводу книги на русский язык; очевидно, по его же просьбе газета “Голос" поместила очень хвалебный отзыв о книге» [20. Л. 18-19].

${ }^{4} \mathrm{Cp}$. требования для вступительных статей в изданиях народной серии: «Предполагается, что читателями народной библиотеки явится полуинтеллигентный пролетарий и крестьянин, а потому язык предисловий должен быть по возможности прост, популярен, не содержать литературных и иных ссылок, специальных терминов и вообще иностранных слов». В предисловие должны были входить «очерк литературной деятельности писателя» и разбор произведения, подразумевающий «разъяснение внутренней, тематической сущности предлагаемого произведения, как бы изложения тех мотивов, в силу которых данное произведение включено в каталог народного издания»; «Примечания <...> в книгах этого издания все, вплоть до объяснения того, что значат слова: энтузиазм, мистики, Альпы, Шекспир, Готентот и т.д. - все, что выходит из круга обыденных понятий и слов, должно быть пояснено построчными примечаниями фактического характера» [9, 11].

\section{ЛИТЕРАТУРА}

1. Багно В.Е. Федор Сологуб - переводчик французских символистов // На рубеже ХІХ и ХХ веков: Из истории международных связей русской литературы. Л., 1991. С. 129-219.

2. Дикман М.И. Поэтическое творчество Федора Сологуба // Сологуб Ф. Стихотворения. (Библиотека поэта. Большая серия. Второе издание). С. 5-74.

3. Стрельникова А.Б. Ф. Сологуб - переводчик поэзии П. Верлена. Томск, 2010.

4. Стрельникова А.Б., Филичева В.В. Библиография художественных переводов, выполненных Ф. Сологубом. Неизданные и несобранные поэтические переводы // Федор Сологуб. Разыскания и материалы : сб. / под ред. М.М. Павловой. М. : Нов. лит. обозрение, 2016. C. 629-709.

5. Голлербах Е.А. Семейные ценности: Федор Сологуб в издательстве «Пантеон» // Федор Сологуб: Биография, творчество, интерпретации. СПб., 2010. С. 39-73.

6. Смиренский В.В. Воспоминания о Федоре Сологубе / вступ. ст., публ. и ком. И.С. Тимченко // Неизданный Федор Сологуб. М., 1997. C. $395-422$.

7. Филичева В.В. «Соединение наших переводов могло бы быть полезно» (Ф. Сологуб и В. Брюсов в работе над переводами П. Верлена) // Текстология и историко-литературный процесс. IV. М., 2016. С. 131-140.

8. Банг Г. Четыре дьявола / пер. Ф. Сологуб; авт. предисл. А.Я. Левинсон. Пб. : Всемир. лит., 1919 (Всемирная литература. Вып. № 38. Дания).

9. Вольтер. Кандид / под ред., с предисл. и прим. Ф.Д. Батюшкова. Пб., 1919 (Всемирная литература. Вып. № 16).

10. Клейст Г. Пентесилея // Клейст Г. Собр. соч. / под общ. ред. В.А. Зоргенфрея. М.; Пг., 1923. Т. 2. С. 97-219.

11. Мопассан Ги де. Сильна как смерть / в пер. под ред. Ф.К. Сологуба. Пг. : Всемирная литература, 1919. Т. 5.

12. Заборов П.Р. Кандид в переводе Ф. Сологуба // Заборов П.Р. Россия и Франция: Литературные и культурные связи. СПб., 2011. С. 85-90.

13. ЦГАЛИ СПб. Ф. 46. Оп. 1. № 58. Материалы о работе издательства в 1923 году (отчет, списки книг, переписка и др.).

14. Верлен П. Собрание стихов / пер. В. Брюсова ; под ред. Ф. Сологуба. СПб., 1911.

15. Верлен П. Стихи, избранные и переведенные Федором Сологубом. СПб., 1908.

16. Неопубликованные переводы Н.С. Гумилёва из Т. Готье и П. Верлена / подг. текста В.В. Филичевой // Русская литература. 2015. № 3. C. $235-242$.

17. Мопассан Ги де. Милый друг / пер. Ан.Н. Чеботаревской ; под ред. Ф. Сологуба. Пг. : Всемирная литература, 1919. Т. 2.

18. Мопассан Ги де. Сильна как смерть / пер. под ред. Ф.К. Сологуба. Пг. : Всемирная литература, 1919. Т. 5.

19. Мопассан Ги де. Лунный свет и другие рассказы / пер. Ал. Чеботаревской // Мопассан Ги де. Полн. собр. соч. СПб. : Шиповник, 1912. Т. XX.

20. ИРЛИ. Ф. 289. Оп. 1. №. 444. Л. 1-14- статья «Рассказы Мопассана»; машинопись с правкой; Л. 15-26 - примечания к т. 7 и 8; машинопись с правкой.

21. СПФ АРАН. Ф. 1026. № 233. Л. 16. По деятельности в издательстве «Всемирная литература». Планы и переписка по плану изданий, списки рукописей, инструкции, отзывы и замечания Крачковского И.Ю. Программа учебного отдела издательства (1919-1925).

22. ИРЛИ. 256 (А.М. Ремизов). Оп. 2. № 30. Документы по деятельности в Литературной студии издательства «Всемирная литература»: циркуляры, постановления, программы лекций и др.

23. Лоррэн Ж. Астарта (Господин Де-Фокас) / пер. Ан. Чеботаревской; предисловие и перевод стихов Ф. Сологуба. СПб., 1911.

24. Сологуб Ф. Смертный лик Гюи де Мопассана // Мопассан Ги де. Полн. собр. соч. : в 30 т. СПб., 1912. С. $265-266$.

25. Верлен П. Стихи, выбранные и переведенные Ф. Сологубом. Пг., М., 1923.

26. ИМЛИ. Ф. 11 (А.Н. Тихонов). Кн. пост. 1218. Д. 13; Протокол от 21 января 1921 года.

27. ИМЛИ. Ф. 11 (А.Н. Тихонов). Кн. пост. 1218. Д. 33; Протокол от 10 мая 1921 года.

28. ИМЛИ. Ф. 11 (А.Н. Тихонов). Кн. пост. 1218. Д. 35; Протокол от 17 мая 1921 года.

29. CEuvres completes de Guy de Maupassant / éd. L. Conard. 29 vv. Paris, 1907-1910.

30. С.Ш. Гюи де Мопассан. Сильна как смерть / пер. и посл. Ф.К. Сологуба. Изд-во «Всемирная Литература» при народном комиссариате по Просвещению. СПб., 1919. С. 240 // Жизнь искусства. № 205-206 (3 авг.) 1919. С. 2.

Статья представлена научной редакцией «Филология» 24 января 2017 г.

\section{F. SOLOGUB AS THE EDITOR IN THE PUBLISHING HOUSE "VSEMIRNAYA LITERATURA"}

Vestnik Tomskogo gosudarstvennogo universiteta - Tomsk State University Journal, 2017, 416, $24-29$.

DOI: $10.17223 / 15617793 / 416 / 4$

Vera V. Filicheva, Institute of Russian Literature (the Pushkin House) of the Russian Academy of Science (Saint Petersburg,

Russian Federation). E-mail: lntfmd@rambler.ru

Keywords: translation; editing; "Vsemirnaya literatura"; F. Sologub; G. de Maupassant.

The paper discusses the work of F. Sologub in the publishing house "Vsemirnaya literatura", organized in 1918. The aim of this paper is to review the editorial principles of the writer and their changes in the course by cooperation. Sologub's work as editor has not previously been a subject of research; the introductory articles by the writer have not been the subject of a separate study. Using the comparative method, the author traces the evolution of the editorial principles of the writer. In "Vsemirnaya Literatura", Sologub was the editor, compiler, author of commentaries and introductory articles for Izbrannye proizvedeniya G. de Mopassana [Selected Works of G. de Maupassant]. Archival studies showed that Sologub prepared six volumes; however, only two of them were published (Bel Ami, Strong as Death). They became the main research material, along with previously unknown documents (Maupassant's Lunnyi svet $i$ drugie rasskazy [Moonlight and Other Short Stories] from Sologub's private library which preserved marginalia and allowed tracing the process of editing, and the unpublished "Preface" to the two volumes of Rasskazy Mopassana [Short Stories 
of Maupassant] stored in the archive of the writer). Until 1918 Sologub had written three introductory articles to the books of translations: his own translations of poems by P. Verlaine, the novel translated by An. Chebotarevskaya and a note for Polnoe sobranie sochineniy Mopassana [Complete Works of G. de Maupassant]. These brief notes by Sologub about the authors or the works were an expression of the subjective attitude of the writer towards the object, they disclosed his own views on issues raised in the novel or on the work of the author. "Vsemirnaya Literatura" had specific requirements for introductory articles. Instructions sent to the editors are a detailed plan of what the preface should contain and how it should be structured. Sologub wrote his introductory article for Izbrannye proizvedeniya G. de Mopassana following this plan. However, the evolution of the principles of editorial work by Sologub did not satisfy the reviewer of the book, N.O. Lerner. He gave a negative review and pointed to the source in one of the articles Complete Works of G. de Maupassant in French (ed. by L. Conard). The review of this publication and its comparison with the content of Sologub's introductory articles shows that the informative part of the preface is completely taken from this source. However, when writing articles, Sologub did not abandon his principles of writing. It is most evident in Sologub's article to his translation of the novel Strong as Death. Comparing the introductory articles of the two periods of the writer, i.e. before 1918 and during the existence of "Vsemirnaya Literatura", the author comes to a conclusion that Sologub, who, at first glance, completely changed an approach to work, managed to save his characteristic manner, i.e. expressed his vision of the works by Maupassant at a professional level.

\section{REFERENCES}

1. Bagno, V.E. (1991) Fedor Sologub - perevodchik frantsuzskikh simvolistov [Fyodor Sologub, an interpreter of French Symbolists]. In: Levin, Yu.D. (ed.) Na rubezhe XIX $i$ XX vekov: Iz istorii mezhdunarodnykh svyazey russkoy literatury [At the turn of the 20th century: From the history of international relations of Russian literature]. Leningrad: Nauka.

2. Dikman, M.I. (1989) Poeticheskoe tvorchestvo Fedora Sologuba [Poetic works of Fyodor Sologub]. In: Sologub, F. Stikhotvoreniya [Poems]. 2nd ed. Leningrad: Sovetskiy pisatel'.

3. Strel'nikova, A.B. (2010) F. Sologub-perevodchik poezii P. Verlena [F. Sologub, a translator of P. Verlaine's poetry]. Tomsk: Tomsk Polytechnic University.

4. Strel'nikova, A.B. \& Filicheva, V.V. (2016) Bibliografiya khudozhestvennykh perevodov, vypolnennykh F. Sologubom. Neizdannye i nesobrannye poeticheskie perevody [Bibliography of artistic translations by F. Sologub. Unpublished and uncompiled poetic translations]. In: Pavlova, M.M. (ed.) Fedor Sologub. Razyskaniya i materialy [Fyodor Sologub. Research and materials]. Moscow: Nov. lit. obozrenie.

5. Gollerbakh, E.A. (2010) [Family values: Fyodor Sologub in the publishing house "Panteon"]. Fedor Sologub: Biografiya, tvorchestvo, interpretatsii [Fyodor Sologub: Biography, creativity, interpretation]. Proceedings of the international conference St. Petersburg: Kosta. pp. 39-73. (In Russian).

6. Smirenskiy, V.V. (1977) Vospominaniya o Fedore Sologube [Memories of Fyodor Sologub]. In: Pavlova, M.M. \& Lavrov, A. (eds) Neizdannyy Fedor Sologub [Unpublished Fyodor Sologub]. Moscow: Nov. lit. obozrenie.

7. Filicheva, V.V. (2016) "Soedinenie nashikh perevodov moglo by byt' polezno" (F. Sologub i V. Bryusov v rabote nad perevodami P. Verlena) ["The combination of our translations could be useful" (F. Sologub and V. Bryusov in translating P. Verlaine)]. Tekstologiya $i$ istorikoliteraturnyy protsess. IV. pp. 131-140.

8. Bang, G. (1919) Chetyre d'yavola [Four Devils]. Translated by F. Sologub. Petersburg: Vsemirnaya literatura.

9. Voltaire. (1919) Kandid [Candide]. Translated from French. Petersburg: Vsemirnaya literatura.

10. Kleist, H. (1923) Pentesileya [Penthesilea]. In: Zorgenfrey, V.A. (ed.) Sobr. Soch. [Works]. Vol. 2. Moscow; Petrograd: Vsemirnaya literatura.

11. Maupassant, G. de. (1919) Sil'na kak smert' [Strong as Death]. Translated from French. Vol. 5. Petersburg: Vsemirnaya literatura.

12. Zaborov, P.R. (2011) Kandid v perevode F. Sologuba [Candide in the translation of F. Sologub]. In: Zaborov, P.R. (2011) Rossiya i Frantsiya: Literaturnye i kul'turnye svyazi [Russia and France: Literary and cultural ties]. St. Petersburg: Petropolis.

13. Central State Archive of Literature and Art, St. Petersburg. Fund 46. List 1. File 58. Materialy o rabote izdatel'stva v 1923 godu (otchet, spiski knig, perepiska $i \mathrm{dr}$.) [Materials on the work of the publishing house in 1923 (report, lists of books, correspondence, etc.)].

14. Verlaine, P. (2011) Sobranie stikhov [Poems]. Translated from French by V. Bryusov. Moscow: Skorpion.

15. Verlaine, P. (1908) Stikhi, izbrannye i perevedennye Fedorom Sologubom [Verses, selected and translated by Fyodor Sologub]. St. Petersburg: Fakel.

16. Filicheva, V.V. (2015) Neopublikovannye perevody N.S. Gumileva iz T. Got'e i P. Verlena [Unpublished translations of N.S. Gumilev from T. Gautier and P. Verlaine]. Russkaya literatura. 3. pp. 235-242.

17. Maupassant, G. de. (1919) Milyy drug [Bel Ami]. Translated from French by A.N. Chebotarevskaya. Vol. 2. Petersburg: Vsemirnaya literatura.

18. Maupassant, G. de. (1919) Sil'na kak smert' [Strong as Death]. Translated from French. Vol 5. Petersburg: Vsemirnaya literatura.

19. Maupassant, G. de. (1912) Lunnyy svet i drugie rasskazy [Moonlight and other stories]. Translated from French by A.N. Chebotarevskaya. In: Maupassant, G. de. Poln. sobr. soch. [Complete Works]. Vol. 20. St. Petersburg: Shipovnik.

20. Institute of Russian Literature. Fund 289. List 1. File 444. Pages 1-14. Stat'ya "Rasskazy Mopassana”; mashinopis's pravkoy [The article “Stories by Maupassant"; typed version with corrections].

21. St. Petersburg Branch of the RAS Archive. Fund 1026. File 233. Page 16. Po deyatel'nosti v izdatel'stve "Vsemirnaya literatura". Plany $i$ perepiska po planu izdaniy, spiski rukopisey, instruktsii, otzyvy i zamechaniya Krachkovskogo I.Yu. Programma uchebnogo otdela izdatel'stva (1919-1925) [On the activities in the publishing house "Vsemirnaya literatura". Plans and correspondence on the plan of publications, lists of manuscripts, instructions, feedback and commentaries of I. Krachkovsky. The program of the educational department of the publishing house (1919-1925)].

22. Institute of Russian Literature. 256 (A.M. Remizov). List 2. File 30. Dokumenty po deyatel'nosti v Literaturnoy studii izdatel'stva "Vsemirnaya literatura": tsirkulyary, postanovleniya, programmy lektsiy $i d r$. [Documents on activities in the Literary Studio of the publishing house "Vsemirnaya literatura": circulars, resolutions, programs of lectures, etc.].

23. Lorraine, J. (1911) Astarta (Gospodin De-Fokas) [Astarta (Monsieur De Focas)]. Translated from French by A.N. Chebotarevskaya. St. Petersburg: Vsemirnaya literatura.

24. Sologub, F. (1912) Smertnyy lik Gyui de Mopassana [The death face of Guy de Maupassant]. In: Maupassant, G. de. Poln. sobr. soch. [Complete Works]. Vol. 20. St. Petersburg: Shipovnik.

25. Verlaine, P. (1923) Stikhi, izbrannye i perevedennye Fedorom Sologubom [Verses, selected and translated by Fyodor Sologub]. Petersburg; Moscow: Petrograd.

26. Institute of World Literature. Fund 11 (A.N. Tikhonov). Item 1218. File 13. Protokol ot 21 yanvarya 1921 goda [Protocol of 21 January 1921].

27. Institute of World Literature. Fund 11 (A.N. Tikhonov). Item 1218. File 33. Protokol ot 10 maya 1921 goda [Protocol of 10 May 1921 ].

28. Institute of World Literature. Fund 11 (A.N. Tikhonov). Item 1218. File 35. Protokol ot 17 maya 1921 goda [Protocol of 17 May 1921].

29. Conard, L. (ed.) (1907-1910) Euvres completes de Guy de Maupassant [Complete Works of Guy de Maupassant]. 29 vols. Paris: L. Conard.

30. Maupassant, G. de. (1919) Sil'na kak smert' [Strong as Death]. Translated from French by F. Sologub. St. Petersburg: Vsemirnaya literatura. Zhizn' iskusstva. 205-206 (3 August). pp. 2. 